JINoP (Jurnal Inovasi Pembelajaran),

Volume 1, Nomor 2, November 2015

\title{
WRITING FACTUAL REPORT: A POTENTIAL WAY TO ENHANCE STUDENT'S CRITICAL THINKING ABILITY
}

\author{
Khoirul Anwar'), Lathifah Iramawaty ${ }^{2)}$ \\ University of Muhammadiyah Gresik \\ Email $^{1)}$ : anwarkhoirul41@gmail.com \\ Email2) : ira930103@gmail.com
}

\begin{abstract}
ABSTRAK
Terdapat banyak perubahan yang terlihat jelas diantara penggunaan KTSP dan kurikulum 2013 dimana kurikulum 2013 dirancang dengan lengkap untuk menghasilkan kompetensi siswa yang memiliki kemampuan berpikir kritis. Karena hal ini adalah tantangan bagi para guru, artikel ini bermaksud untuk mendiskusikan dan menganalisis bagaimana menulis laporan faktual dapat meningkatkan kemampuan berpikir kritis para siswa. Pentingnya kemampuan berpikir kritis dan strategi yang digunakan untuk meningkatka kemampuan berpikir kritis siswa juga manjadi salah satu bahasan artikel ini. Tujuan penulisan artikel ini lebih lanjut untuk memberikan deskripsi jelas terhadap kemampuan berpikir kritis dan prosedur yang disarankan untuk menggunakan metode menuliskan laporan faktual pada pengajaran Bahasa Inggris sebagai bahasa asing. Lebih lanjut, menggunakan metode menuliskan laporan faktual secara jelas dapat menmbantu meningkatkan kemampuan berpikir kritis siswa yang merupakan tujuan paling utama dalam pengajaran Bahasa Inggris sebagai bahasa asing pada masa ini.
\end{abstract}

Kata kunci: Laporan Faktual, Berpikir Kritis Kemampuan.

\begin{abstract}
There are a lot of changes which are quite prominent between KTSP and 2013 curriculum in which the latest one was highlydesigned for producing students' competencies to have critical thinking ability. Since this is challenging for teachers, this article is to discuss and analyze about how writing factual report enhances students' critical thinking. The importance of critical thinking and strategies used to increase students' ability to think critically is also discussed. The aim of this article is further to give aclear description of critical thinking and the suggested procedures of using writing factual report in EFL teaching. Furthermore, using writing factual report can definitely help enhance students' critical thinking which is extremely as the most important goal in EFL teaching nowadays.
\end{abstract}

Keywords: Factual Report, Critical Thinking Ability.

\section{INTRODUCTION}

Actually the 2013 curriculum was designed to produce competent students to face the challenging problems by encouraging them to make observations, ask questions, and communicate what they have earned or they have known after receiving learning materials. To achieve that goal, learning process is divided into four main competencies such as the dignity to God; attitude; knowledge application; and critical thinking. Of the four main competences, it seems that critical thinking should be equally and prominently considered by all teachers in which it is hopefully to develop students' independent learning. 
Critical thinking is actually a matter of maximizing the power of cognitive skills of someone in order to yield maximum learning output. Therefore, the process of the thinking should be clearly managed especially the purposes and the reasons of learning to be noted, and then to optimize thinking skill process by problem solving, prediction skills, decision making, etc., all of which are mainly and effectively considered to the thinking types and tasks (Diane: 2003). Critical thinking, therefore, is persons' thinking ability to assess some issues that allow people to make a selfargument which was reasoned. Many ways can be taken in processing ideas from the information which people get to make it clear, deep and reasoned. Those ways are identifying, asking questions, analyzing, evaluating, and communicating to assess something to find the validity of the issue. One of the advantages which people get if they are used to thinking critically is they become a good decisionmaker, which is so helpful to reduce some negative impacts in their life. Thus, good development in critical thinking seems important to students nowadays.

Critical thinking ability is placed in the fourth main competency of the curriculum because it has been established as a noticeable learning objective. To accomplish this, the teachers should maintain teaching strategies that enhance students' critical thinking by engaging them in teaching learning process. Basically, teaching students to think critically is challenging for teachersbecause it is still relatively new and quite complex. There are many ways that the teachers can use to enhance students' critical thinking in EFL teaching, such as cooperative learning strategy, discussion, using question, and writing assignments.
Starkey (2010) generally argues that critical thinking involves two terms that are often used interchangeably; they are problem solving and reasoning. More specifically, critical thinking includes the ability to: make observations, listen attentively to others, recognize and define problems, be curious, ask relevant questions, and use multiple resources to find facts, challenge and examine beliefs, assumptions, and opinions, assess the validity of statements and arguments, know the difference between logical and illogical arguments, make wise decisions and judgments, and find valid solutions. It is apparent that critical thinking is related to the processes of learning (Moon: 2008), even though it is not all about learning. It seems that it is a process we get about knowledge by generating particular ways to acquire it. The knowledge that we manage can be from internal experiences (the things that we already know) and external experiences (the knowledge taken from other people's experiences) in which all are gathered to help process our own understanding, evaluation, synthesis and analysis.

Critical thinking needs particular skills and attitudes (Cottrell: 2005) which include: Identifying other people's positions, arguments and conclusions; Evaluating the evidence for alternative points of view; Weighing up opposing arguments and evidence fairly; Being able to read between the lines, seeing behind surfaces, and identifying false or unfair assumptions; Recognizing techniques used to make certain positions more appealing than others, such as false logic and persuasive devices; Reflecting on issues in a structured way, bringing logic and insight to bear; Drawing conclusions about whether arguments are valid and 
justifiable, based on good evidence and sensible assumptions; Presenting a point of view in a structured, clear, well-reasoned way that convinces others. In addition, the practice of argument reconstruction in critical thinking can be practiced into some following ways: extraneous material and defusing the rhetoric, logical streamlining, implicit and explicit reasoning, connecting premises, making generalisations by the practical reasoning, balancing costs, bene?ts and probabilities, explanations as conclusions, and causal generalisations (Bowell and Kemp: 2005).

Based on Crews, Anderson, and Timothy's finding (2007), the argument that is related to critical thinking ability entails nonetheless two schemes. All opinions are built deductively or inductively, in that the success of deductive arguments is assessed in terms of what philosophers appeal validity and soundness, while inductive arguments are evaluated along a scale from weak to strong.

Writing assignment is one of the ways which is potential to enhance students' critical thinking skill. A study of teaching critical thinking in writing assignment by Cavdar \& Doe (2012) showed a significant improvement in students critical thinking skill in producing a coherent opinion and strong arguments.This is also confirmed by an experimental study of Quitadamo \& Kurtz (2007) that critical thinking improvement in the writing group was approximately nine times greater than the nonwriting group. It can be concluded that writing assignment is potential way to enhance students' ability to think critically particularly by using factual reports. Factual reports include an issue, news or cases that are happening in students society or environment which require a serious attention. By facing the complex problems, the students will be excited to share their arguments, identifying, asking questions, gaining some information from other sources, analyzing that problem through writing assignments. If this is done continuously, it will give a positive influence in their ability to think critically.

This article reviews and analyzes about the importance of writing factual report to enhance students' critical thinking. The importance and the strategies used in enhancing students' critical thinking are also discussed. By reviewing and analyzing this, teachers will have a clear description of the importance of critical thinking and the guidelines of using writing factual report in EFL teaching. It will help enhance students' critical thinking ability which is highly important to the teachers in teaching English nowadays.

\section{CRITICAL THINKING}

Critical thinking is an essential skill which people have to develop. Many definitions are described by researchers such as Diane (2003) who states that critical thinking is the persons' ability to analyze and assess issues or information. Others define that critical thinking is the art of breaking down and evaluating thinking with a view of improving it (Paul \& Elder: 2006). In short, critical thinking is persons' skills in thinking to review, analyze and assess information to find the validity of it.

Actually, there is a significant difference between critical thinkers and passive thinkers. Critical thinkers usually open-minded in assessing information. As the previous researchers' explanation that critical thinkers raise important questions and problems, then formulate the problems clearly, assess relevant 
information, use abstract ideas, openminded in thinking, and communicate it effectively (Bowell and Kemp: 2005). It is also reinforced by Paul \& Elder (2006) who argue that a good critical thinker mostly is able to formulate main problems clearly. They tend to gather some relevant information about the problems to make a well-reasoned conclusion and solution towards that problem then communicate them effectively.

While, passive thinkers tend to be more passive in arguing a reasoned statement and close-minded, passive thinkers suffer a limited view, they usually use yes or no to answer questions and view their perspective as the only sensible one and their facts as the only ones relevant (Bowell and Kemp: 2005).

Related to these issues, critical thinking ability can be trained through several processes such as observing, questioning, gathering relevant information from the other sources, interpreting it clearly, recognizing and assessing, making a conclusion and solution of that problem and communicating it effectively.

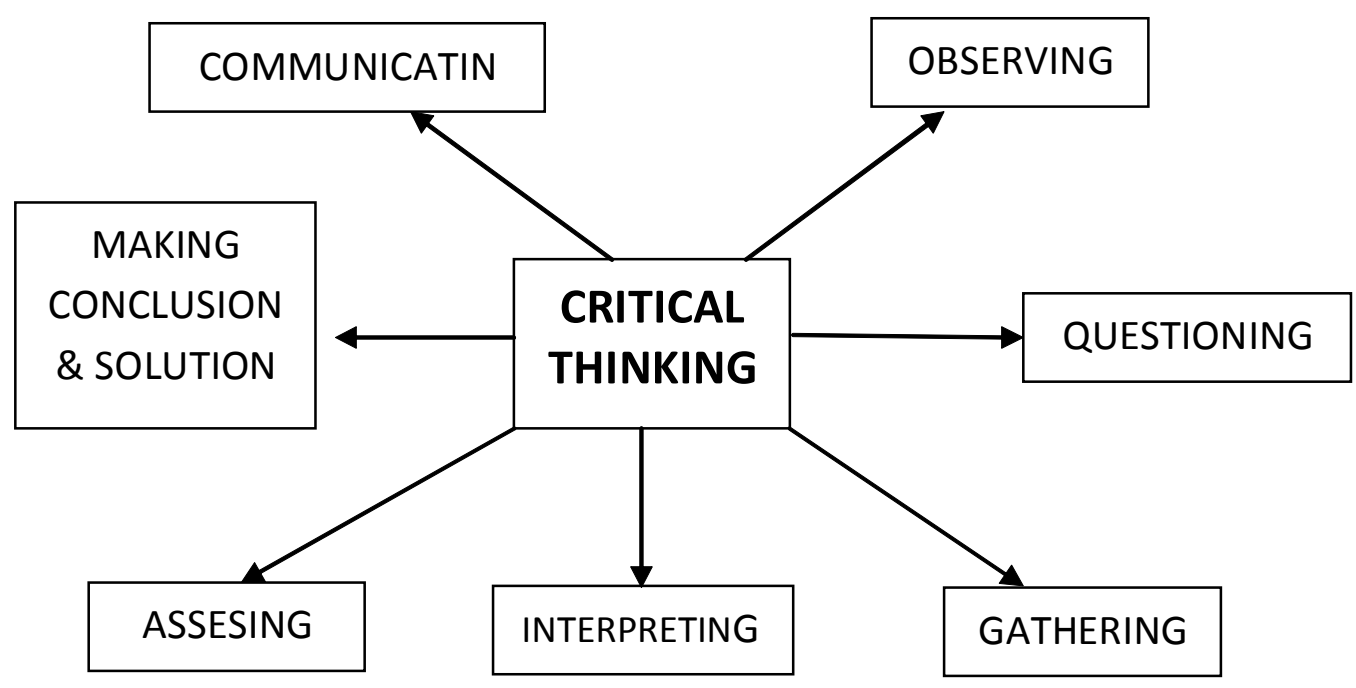

Process of Thinking Critically (Bowell and Kemp: 2005)

THE IMPORTANCE OF CRITICAL THINKING FOR STUDENTS IN LEARNING ENGLISH

The most successful classrooms mean classrooms which encourage the students to think for themselves and engage in critical thinking (Diane: 2003). Thus, promoting critical thinking into the teaching learning process becomes an important one. Why is it important? It is because the quality of student resulting from classroom learning process depends on the quality of students' thought.
Critical thinking offers many benefits to the students. Paul \& Elder, (2006) critically evaluate that students who are used to think critically, learn the content deeper. They are better able to explain and apply what they learn to their everyday life, connect what they learn in a class with other classes. Besides, they tend to ask more and develop better questions in class. They understand the textbook and follow directions better. Moreover, they understand more and better in writing. Last, they become more motivated learners in general and progressively easier to teach. 
In English learning, critical thinking skill is extremely needed. In order to create a certain quality in the English learning process, students have to be a critical thinker. Students use their critical thinking ability to assess information, developing critical questions, solving the problem clearly, making a good decision, and be an efficient communicator. Also, it will increase students' engagement in the English learning process. For these reasons, critical thinking should be established in every EFL teaching.

\section{STRATEGIES AND TECHNIQUESTO DEVELOP STUDENTS' CRITICAL THINKING}

Teaching students to think critically is still relatively new and quite complex. That is why teaching students to think critically is challenging for teachers. The teachers should find an appropriate strategy to do this. There are many strategies and techniques which can be used to teach critical thinking. Here are some strategies which can be used to enhance students' critical thinking:

\section{Cooperative Learning Strategies}

Cooperative Learning is a method which encourages students to work in a group to do a specific task. It also helps to build students' ability to work as a team. Besides, cooperative learning has a positive possibility to enhance students' critical thinking skill. It was proven by a study conducted by Klimoviene, Urboniene, and Barzdziukiene (2006). The result of the study showed that Cooperative Learning is an effective technique for developing sudents' critical thinking skill. The final result of assessment of students' critical thinking skill is significantly improved.

\section{Using Questions}

The question is one of many techniques which indicates developing thinking skills. An experimental study by Alexander et.al (2010), showed that the result of the study declared the effectiveness of question technique in enhancing critical thinking.

\section{Using Writing Assignments}

Writing assignment offers a high possibility of enhancing students' critical thinking skill. Quitadamoand Kurtz (2007) conducted an experimental study in that the researchers divided the participants into two groups, writing and non-writing. The result of this study showed that writing students significantly improved their analysis and inference skills whereas nonwriting students did not. Writing students also improved their evaluation skill much more than non-writing students.

\section{Debate}

Debate is one of the highly influential techniques for enhancing students' ability to think critically which is usually applied in the classroom. The structure of debate mostly a team or a pair. This technique starts by promoting important problems which have pro contra, and students are to argue.

\section{CONTRIBUTION OF WRITING FACTUAL REPORTS}

Writing is a written tool used by people for communicating their thought and ideas which can help people obtain the information they get from their experience. Writing has a potential role to enable higher order thinking, especially when we think that writing is an occasion process to think through some arguments, make reasons and persuations (Resnick, 1987). Gooblar (2014) mentions one of the important 
benefits taken from writing that it is not only to encourage the students to think deeper into the subjects but also help them become better writers. Writing is a space for students to develop their selfarguments towards the topic. Students are able to understand the information better when they write. Writing not only help them think deeper but also increase students' engagement with the subject of learning. Writing helps students learn and identify the concepts, and think about the ideas which finally help students develop their communication skill.

Writing therefore is one of the best techniques which can improve students' ability to think critically in that the influence

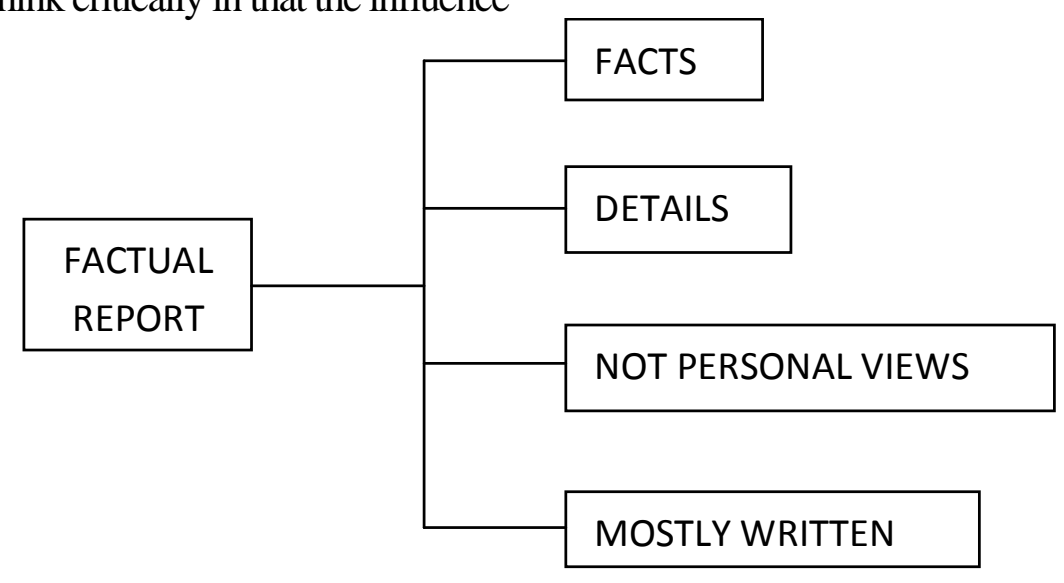

The characteristics of factual report mostly use a fact to explain something, give details about the topic, does not contain personal views, is mostly written but can also be presented orally. Gaining the facts can deepen their understanding about the topic. They are trained to assess something to discern whether it is a fact or not. Besides, giving the details of the topic forces them to gain deeper information towards the topics. This situation will train students to build ideas. In building ideas, they are trained to link an idea with other ideas which are relevant. Thus, those steps are good for developing their critical thinking skill. on critical thinking is quite higher. Several studies showed that writing assignments improve sudents' ability to think critically. Quitadamo and Kurtz (2007) declare that there is a significant improvement in students' analysis and inference skills of writing students while non-writing students did not.

Factual report is a kind of text types of writing that provides the information about something. The topic of factual reporting can be a specific thing, human, animal, natural phenomena, and social phenomenon. Factual report, in this case, is used as a way to gain a better understanding of something.

FACTS

THE SUGGESTED PROCEDURES OF USING WRITING FACTUAL REPORTS

The proposed procedures below are intentionally linked to the common three steps of teaching that is pre-teaching, whilst-teaching, and post teaching activities. The detail sample procedures are given in the following:

\section{Pre-teaching Activities \\ Motivating the students to think critically}

Training students to think critically is quite complex which usually needs hard efforts. Without strong motivation, students 
will be unwilling to engage in this process. Therefore, the teachers have to gain their interest first. For gaining students' interest, the teachers should explain the importance of critical thinking. Giving clear explanation is the best strategy to attract their attention. Better if the teachers use a story telling to make it more interesting

\section{Brainstorming}

In this activity, the teacher poses an interesting question on which students are likely to have an opinion.

\section{Explaining the main activities}

In this section, the teachers explain to the students about the activity which should be done in this course. The teacher explains each step that students should take in order to achieve the course' goal.

\section{Whilst-teaching Activities Grouping}

The teacher divides students into groups in which each possibly consists of 5 people. The teacher can give a picture of social issue for each group. By working in a group, students will have an opportunity to share their ideas, learn how their friends' views towards the issue and get a clear description about it. Besides, they can ask any questions related to the topic and discuss them with each other. Questioning is an essential part in gaining students' thinking skills.

\section{Reading}

In this part, the teacher asks students to gather some information about the topic/ issue. In gathering some facts, the students can access the internet, read a book or read an article. In evaluating the data, students have to determine whether it is fact or not.

\section{Making an outline}

After gaining some information from many sources, the teacher asks students to make an outline of factual report individually. An outline has a function as a planner. It can be used to develop the main topic of the paragraph and evaluate a coherent structure of paragraphs.

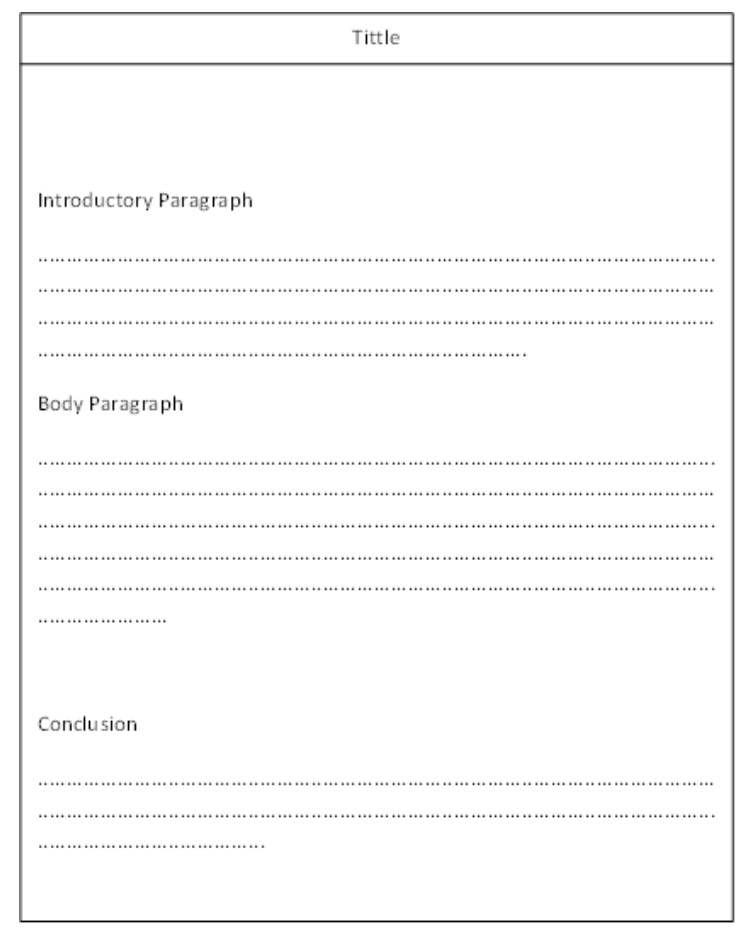


Building an idea of that outline into a draft paragraph

The teacher asks students to put the students' idea of their outline on paper and build a draft paragraph.

\section{Revising the draft paragraph in pair-work}

Next, the teacher asks students to work in pair and do some revisions of their work in pairs. It can be an error of spelling, grammar, or ideas which are not coherent. Some recommended ideas are to modify the structure of draft paragraph. Working in pairs can produce a better opinion.

\section{Developing draft paragraph}

In this section, teacher can ask students to develop their draft paragraph into good paragraph individually. In order to make a well-developed writing paragraph, students have to learn to elaborate each section by using transition, such as : after, next, first, second, etc. Then, they should link the paragraph and connect it with conjunction. Making contrast and opposition are also needed.

\section{Giving specific details}

The teacher asks students to give more specific details. The paragraphs must use a factual information to give the reader a better understanding of the topic.

\section{Post-Teaching Activities Giving feedback}

Feedback is an important tool that teachers can use to improve learning. Information which teachers get during the teaching learning process should be responded. Teachers can review the comment of class discussion, identify some ideas which are incorrect, show an alternative ways to link a relevant paragraph and so on. In this situation, teachers should spend more time for helping students gain a better understanding. Giving feedback can also enhance the quality of students' learning and performance in the next course.

\section{Closing}

In this part, the teacher asks students to make a conclusion about the learning session. It can be done by asking them to identify the most important point they have learned so that they may find their followup needs by doing a writing task continously to improve their critical thinking skill further.

\section{CONCLUSION}

Good development of critical thinking is needed by students at language classes in that accordingly this maximum implementation in English learning has to be considered. Thus, by promoting critical thinking into the EFL teaching, it automatically creates possible opportunities of processing students to be critical thinkers.

Writing factual report is one technique which can promote students' critical thinking ability in which it is a text which provides the paramount and useful information to be developed analytically. By writing the factual report, in fact, the students are trained to assess something to determine whether it is a fact or not which guides them to gain deeper understanding towards the tropics. This situation will train them to build natural ideas because they are trained to link those ideas with other relevant ones. Based on the review and analysis, writing a factual report can possibly enhance students' critical thinking ability. 


\section{REFERENCES}

Alexander, Martha E., Commander, Nannette., Greenberg, Daphne \& Ward, Teressa (2010). Using the Four-Questions Technique to Enhance Critical Thinking in Online Discussion. MERLOT Journal of Online Learning and Teaching 2, Vol.6 (2010): 409-515.

Bensley, D. Alan. 2010. A Brief Guide for Teaching and Assessing Critical Thinking in Psychology. http://www.psychologicalscience.org/ index.php/ publications/observer/ 2010/december-10/a-brief-guidefor-teaching-and-assessing-criticalthinking-in-psychology.html (accessed 2013-12-29).

Bowell, Tracy, and Kemp, Gary. 2005. Critical thinking: a concise guide. New York: Library of Congress Cataloging in Publication Data.

Cavdar, Gamze \& Doe, Sue (2012). Learning Through Writing: Teaching Critical Thinking Skills in Writing Assignment. Colorado State University.

Cottrell, Stella. 2005. Critical Thinking Skills: Developing Effective Analysis and Argument. New York: Library of Congress.

Crews-Anderson, Timothy A. 2007. Critical Thinking and Informal Logic. Tirril: Published by Humanities-Ebooks.co.uk

Diane F. Halpern. 2003. Thought and knowledge: an introduction to critical thinking. New York: Lawrence Erlbaum Associates, Inc. Goodin, Heather J. \& Stein, David (2009). The Use of Deliberative Discussion to Enhance the Critical Thinking Abilities of Nursing Students. Journal of Public Deliberation, Vol. 5 Issue 1.
Elder, Linda \& Paul, Richard. Critical Thinking Development: A Stage Theory.http://www.criticalthinking.org/ pages/critical-thinking-development-astage-theory/483 (accessed 2013-1227).

Gooblar, David. 2014. The Obvious Benefits of In-Class Writing Assignment. https://chroniclevitae. com/news/588-the-obvious-benefitsof-in-class-writing-assignments (accessed 2013-12-28)

Khalil, Farouq M. Teaching Writing to Post-Secondary Students: Procedures and Technicalities in an EFL Classroom. AN-Najah University.

Klimoviene, Giedre., Urboniene, Jurate \& Barzdziukiene, Raminta (2006). Developing Critical Thinking Through Cooperative Learning. Lithuanian University of Agriculture 9 Moon, Jennifer. 2008. Critical Thinking: an exploration of theory and practice. New York: Library of Congress Cataloging in Publication Data.

Paul, Richard \& Elder, Linda (2006). The Miniature Guide to Critical Thinking Concepts and Tools. The Foundation For Critical Thinking.

Quitadamo, Ian J. \& Kurtz, Martha J (2007). Learning to improve: Using Writing to Increase Critical Thinking Performance in General Education Biology. CBE-Life Sciences Education Vol. 6

Resnick, Lauren B (1987). Education and Learning to Think. Washington, D.C. : The National Academies Press.

Starkey Lauren. 2010. Critical thinking skills success in 20 minutes a day. New York: Learning Express, LLC. 